\title{
IGNITION PATTERNS INFLUENCE FIRE SEVERITY AND PLANT COMMUNITIES IN PACIFIC NORTHWEST, USA, PRAIRIES
}

\author{
R. Adam Martin and Sarah T. Hamman* \\ Center for Natural Lands Management, \\ 120 East Union Avenue \#215, Olympia, Washington 98501, USA \\ *Corresponding author: Tel.: +1-360-790-4180; e-mail: shamman@cnlm.org \\ ABSTRACT

\section{RESUMEN}

In the prairies of the Pacific Northwest, USA, fire has been reintroduced as a tool for reducing non-native, invasive plant cover and promoting the growth and establishment of native plant communities. Head fires and backing fires are the two primary ignition patterns used to complete most prescribed burns, but the relative effectiveness of these two methods on invasive plant control and native enhancement is unknown. A clear understanding of the relationship between fire behavior, fire severity, and fire effects on vegetation and how these metrics are affected by fire ignition patterns could help managers fine tune burn prescriptions to better achieve ecological objectives. We used observations from five prescribed burns in the south Puget Sound prairies of western Washington, USA, to evaluate the relationship between intensity, severity, and effects. Additionally, we collected data from two burns on how ignition patterns affected these relationships. We found a significant positive correlation between maximum surface temperature and fire severity, and a decline in perennial taxa with increasing fire severity. We also found that surface temperatures did not differ between ignition patterns, but a greater area burned at mod-
En las praderas del Pacífico Noroeste, EEUU, el fuego ha sido reintroducido como una herramienta para reducir la cobertura de plantas invasoras no nativas y para promover el crecimiento y establecimiento de comunidades de plantas nativas. Los fuegos frontales y de cola son los dos patrones primarios de ignición utilizados para completar la mayoría de las quemas prescriptas, aunque la efectividad relativa de estos dos métodos en el control de plantas invasoras y el aumento de las nativas es desconocida. Un claro entendimiento de la relación entre comportamiento del fuego, severidad del fuego, y efectos del fuego en la vegetación, y como estas medidas son afectadas por los patrones de ignición del fuego podrían ayudar a los gestores a mejorar las prescripciones de quema para un mejor logro de los objetivos ecológicos. Nosotros utilizamos observaciones de cinco quemas prescriptas en el sur de las praderas de Puget Sound en el oeste de Washington, EEUU, para evaluar la relación entre la intensidad, la severidad, y los efectos del fuego. Adicionalmente, tomamos datos de dos quemas para determinar cómo los patrones de ignición afectaron estas relaciones. Encontramos una correlación significativa y positiva entre las temperaturas máximas de superficie del suelo y la severidad del fuego, y una declinación en los taxa de plantas perennes con el incremento de la severidad del fuego. También encontramos que la temperatura de la superficie no difirió entre los patrones de igni- 
erate severity in backing fires than in head fires. Ignition patterns differentiated plant communities by changing the number of species present within different life form categories. However, this response was contingent upon site history and pre-burn conditions. Native perennial forbs were associated with head fires in a site with high pre-existing native plant species richness. Native and exotic forbs were associated with backing fires at a site with low pre-existing native plant species richness. Thus, managers may want to consider ignition patterns when planning burn prescriptions in order to achieve particular ecological objectives. ción, pero con severidad moderada, se quemó una superficie mayor con fuegos de cola que con fuegos frontales. Los patrones de ignición diferenciaron comunidades de plantas cambiando el número de especies presentes dentro de las distintas categorías de formas de vida. Sin embargo, esta respuesta fue contingente sobre la historia del sitio y las condiciones de pre-quema. Las herbáceas perennes nativas fueron asociadas con fuegos frontales en un sitio con pre-existencia de alta riqueza de especies de plantas nativas. Herbáceas nativas y exóticas fueron asociadas con fuegos de cola en un sitio con una baja riqueza previa de especies nativas. De esta manera, los gestores pueden considerar los patrones de ignición cuando planifican quemas prescriptas para lograr objetivos ecológicos particulares.

Keywords: backing fire, community analysis, fire intensity, fire severity, head fire, ignition pattern, prescribed fire, restoration, vegetation

Citation: Martin, R.A., and S.T. Hamman. 2016. Ignition patterns influence fire severity and plant communities in Pacific Northwest, USA, prairies. Fire Ecology 12(1): 88-102. doi: 10.4996/fireecology.1201088

\section{INTRODUCTION}

Prescribed fire, or ecological burning, is a primary tool used for fuel reduction and restoration in ecosystems throughout the world (Agee 1996, Covington 2003, Brown et al. 2004, Pyke et al. 2010, Ryan et al. 2013). Prescribed fire is typically applied within specific windows of wind speed and direction, relative humidity, and temperature to minimize risk of escape and limit smoke emissions. Additionally, the fire ignition patterns used during a prescribed fire operation depend on topography, available resources (trained personnel, engines, etc.), surrounding vegetation, and relationship to the wildland-urban interface. While fire behavior is complex, strong relationships have been found between certain metrics of fire intensity and fire severity, and fire severity and habitat structure in shrublands and forests (Keeley 2009). In these systems, surface temperatures and duration of heating (fire intensity metrics) are positively correlated with surface duff consumption, a measure of fire severity (Hartford and Frandsen 1992). Also, the degree of biomass loss, either aboveground or belowground, influences the postburn vegetation community recovery trajectory in forests (Turner et al. 1999, Schoennagel et al. 2004, Perry et al. 2011, Ryan et al. 2013). These relationships between fire intensity, fire severity, and plant community response have not been well established for grassland systems.

Ignition patterns could influence fire intensity, severity, and vegetation response to fire for a number of reasons. First, backing fires and head fires create fundamentally different types of fire. Head fires are flashy, wind-driven fires with short residence times, high rates 
of spread, and longer flame lengths. Backing fires are primarily fuel-driven fires, with long residence times, low rates of spread, and shorter flame lengths. These differences could have specific first- and second-order impacts on community response. In grasslands, fire intensity (as measured by maximum surface temperatures) and severity (as measured by organic matter removed) are likely to be higher in backing fires than in head fires. Variation in maximum temperatures and heating time as a result of the ignition pattern could have direct impacts on plant tissue death and indirect impacts on seed germination the following season. These impacts may differ based on plant life form and origin; perennials with buds less than $2 \mathrm{~cm}$ belowground are much more susceptible to direct fire impacts than annuals with a sufficient seed bank or long-lived woody species with insulating bark (Pyke et al. 2010). Additionally, fire-adapted native plant species may be more resistant to longer duration or higher temperature fires that are required to remove introduced species (DiTomaso et al. 2006), providing an opportunity to utilize certain ignition patterns for invasive control. For these reasons, managers may use different ignition patterns during a prescribed burn to influence fire behavior, severity, and community response (Kilgore and Curtis 1987 , Van Wilgen et al. 2004).

In the Pacific coastal grasslands of the United States, the invasion of perennial rhizomatous grasses, nitrogen-fixing leguminous shrubs such as French broom (Geista monospessulana [L.]) L.A.S. Johnson) and Scotch broom (Cytisus scoparius [L.] Link), and fire-adapted annual grasses such as cheat grass (Bromus tectorum L.) have fundamentally changed the structure and functioning of native grassland communities (Seabloom et al. 2003, Haubensak et al. 2004). The presence of invasive species and increased cover of fire-sensitive mosses and lichens in Pacific Northwest (PNW) prairies have increased the fuel loads above historical levels (Foster and
Shaff 2003). Aboriginal burning was likely frequent ( $<5 \mathrm{yr}$ intervals) in PNW prairies, and used to promote an open structure that supported important non-grass food sources, such as geophytes (e.g., Camassia quamash [Pursh] Greene), berries (e.g., Fragaria virginiana Duchesne), and ferns (e.g., Pteridium aquilinum [L.] Kuhn) (Wray and Anderson 2003, Storm and Shebitz 2006). The high frequency of burns likely produced fires of low intensity and severity due to the patchy, open nature of this native bunchgrass system (Boyd 1999).

Current restoration practices in PNW prairies involve periodic prescribed burning to remove invasive species, reduce moss and litter build-up, and promote native fire-adapted prairie vegetation (Hamman et al. 2011). However, no work in this system has examined the complex relationships between fire intensity, severity, and effects, or how these relationships might be altered by ignition patterns. We address this issue with three questions.

1. What is the relationship between fire intensity, fire severity and vegetation response to fire?

2. Does fire ignition pattern differentially impact fire intensity and severity?

3. Does fire ignition pattern differentially alter the response of native and exotic plant life forms to prescribed fire?

Answers to these questions will help managers develop more sophisticated burn plans that utilize various ignition patterns to achieve species-specific and structural ecological objectives.

\section{METHODS}

\section{Sites}

To elucidate relationships between fire intensity, severity, and effects, we collected data from five different prescribed burns, conducted on five prairies owned by county, state, and 
non-profit agencies in the South Puget Sound, Washington, USA. The five sites were Glacial Heritage Preserve $\left(46^{\circ} 53^{\prime} 37.32^{\prime \prime} \mathrm{N}, 123^{\circ} 3^{\prime}\right.$ 8.64" W), Tenalquot Preserve $\left(46^{\circ} 53^{\prime}\right.$ 50.6394" N, 122 43" 53.0394" W), Mima Mounds Natural Area Preserve $\left(46^{\circ} 52^{\prime}\right.$ 13.7994" N, $123^{\circ} 2^{\prime}$ 25.44" W), Scatter Creek Wildlife Area $\left(46^{\circ} 50^{\prime} 20.76^{\prime \prime} \mathrm{N}, 122^{\circ} 59^{\prime}\right.$ 37.32" W), and West Rocky Wildlife Area $\left(46^{\circ} 53^{\prime} 33.36^{\prime \prime} \mathrm{N}, 122^{\circ} 52^{\prime} 11.2794^{\prime \prime} \mathrm{W}\right)$. All five prairies have similar glacial outwash soils (Spanaway, or Nisqually, or both soil types) and similar management goals, but are at different stages in the restoration process. All prairies have been actively managed to reduce the cover of invasive species, recover native forbs and bunchgrasses, and act as reintroduction sites for rare species such as the Taylor's checkerspot butterfly (Euphydryas editha taylori [W.H. Edwards 1888]; state endangered, federally endangered) and golden paintbrush (Castilleja levisecta Greenm; state endangered, federally threatened). Prescribed burns have occurred annually across different sections of all prairies since 2001, creating slightly different fire histories in each unit. The goal for these sites is to eventually achieve a fire return interval of $2 \mathrm{yr}$ to $5 \mathrm{yr}$ for any given patch of prairie. The burns evaluated for this study took place between 15 August and 15 September over two years (2011 and 2012) and were characterized as having either predominantly low or moderate severity.

Two of the sites, Glacial Heritage Preserve and Tenalquot Preserve, were studied more closely for ignition pattern treatment effects on fire intensity, fire severity, and vegetation communities. The 12.2 ha unit at Glacial Heritage was burned in August 2011, marking the third fire in 10 years at that location. The 8.1 ha, August 2012 fire at Tenalquot was the first known fire to occur since European settlement of the area. Approximately half of each burn unit experienced a head fire and half experienced a backing fire. Prior to both burns, sites were boom-sprayed with a grass-specific her- bicide (sethoxydim) in the spring to kill non-native grasses and then sprayed with a broad-spectrum herbicide (glyphosate) during the fall post-fire flush to kill fast-growing non-native forbs. This integrated treatment of fire and herbicide has been the most successful management strategy to control invasive species and prepare sites for seed augmentation (Stanley et al. 2008). Areas were then seeded with Roemer's fescue (Festuca roemeri [Pavlick] E.B. Alexeev) two months post fire. Despite findings of deleterious effects of certain broadleaf herbicides on seed germination of both monocots and dicots in dry grasslands (Wagner and Nelson 2014), we have not seen any evidence of pre-emergent, off-target effects of grass-specific (A. Lincoln, Center for Natural Lands Management, Olympia, Washington, USA, unpublished data) or broad-spectrum (Stanley et al. 2008) herbicides on prairie species when they are applied at appropriate times. For this study, herbicide and seeding treatments were applied evenly across the burn units, while fire ignition pattern was not, allowing evaluation of head fires versus backing fires within this restoration context.

\section{Sampling Design}

At all five sites, we established five to ten transects that were either $5 \mathrm{~m}$ or $10 \mathrm{~m}$ apart, depending upon size and shape of the burn unit. We collected plant community and fire severity data in $1 \mathrm{~m}^{2}$ quadrats placed every 10 $\mathrm{m}$ along each transect. At Glacial Heritage and Tenalquot, there were 50 quadrats per burn unit; at Mima Mounds, Scatter Creek, and West Rocky, there were 100 quadrats per burn unit. At Glacial Heritage and Tenalquot, where ignition pattern treatments were applied, there were 21 to 29 quadrats per ignition pattern treatment (sample size was dependent upon where ignition lines met within the burn unit), so sample size between ignition patterns and sites varied slightly. Due to the fact that we could not replicate ignition pattern treat- 
ments within each burn, ignition pattern data are pseudo-replicated within a site (Hurlbert 1984, but see Oksanen 2003 for a rebuttal). Despite this design challenge, we still believe that these data provide a unique opportunity to evaluate fire behavior, severity, and effects associated with fire ignition patterns.

\section{Fire Intensity}

Fire intensity is typically characterized by measures of fire temperature and rate of spread (RoS; Keeley 2009). In all five burn units, we measured maximum temperature reached at the soil surface using 10 sets of copper tags painted with 24 temperature sensitive paints (OmegaLaq, Stamford, Connecticut, USA), ranging from $79^{\circ} \mathrm{C}$ to $760^{\circ} \mathrm{C}$, in increments of approximately $28^{\circ} \mathrm{C}$. We placed tags in 10 randomly chosen quadrats within each burn. At Glacial Heritage and Tenalquot, half of these quadrats experienced a head fire and half experienced a backing fire ( $n=5$ per burn). At these two sites, we measured RoS by timing the spread of the flaming front over a $1 \mathrm{~m}$ distance at two to four different locations within each burn treatment (head fire, backing fire). Additionally, we visually estimated flame lengths at the same points at which RoS measurements were taken to help characterize the fire intensity. We collected these observational data solely for the purpose of characterizing the burns and therefore did not subject them to statistical analysis.

\section{Fire Severity}

We classified fire severity using the Grassland Burn Severity classification scheme used by the National Park Service (USDI National Park Service 2003). Briefly, the scheme includes five measures of burn severity: unburned, scorched, lightly burned, moderately burned, and heavily burned. These categories are based on the amount of organic matter consumed and how deep the soil charring oc- curred, with complete consumption and soil charring occurring in moderately and heavily burned categories. We recorded the percent cover of each fire severity category in the same $1 \mathrm{~m}^{2}$ plots monitored for vegetation in each burn unit one week post burn.

\section{Plant Community}

We collected species richness data in all quadrats across each burn unit. We collected pre-burn and post-burn data at the height of the growing season, between 1 June and 15 June each year. For analysis, we collapsed the data from each plot from species level to origin (native or exotic) and life form (annual or perennial; forb, grass, or shrub) to control for the species differences between sites and to facilitate comparisons with other ecosystems.

\section{Data Analysis}

The relationship between fire intensity, fire severity, and vegetation response to fire. The data used for this analysis consisted of quadrat-level fire severity and maximum temperature data from all five prairies. We conducted analyses in either PCORD v6 (MjM Software Design, Glenneden Beach, Oregon, USA) or R (version 3.1.1; R Core Team 2014). Since the fire severity data were multivariate in nature, and cover values of the five severity classes summed to $100 \%$, we created a Fire Severity Index (FSI). We used a Bray-Curtis distance measure and a 1-axis polar ordination with subjective poles (ranging from least to most severe) to create a score. This score had negative values, so we added 1 to ease interpretation: lower values correlated with unburned and light severity, and higher values correlated with moderate and high severity. We ran linear regressions on the 50 quadrats across the five prairies that had fire intensity measures taken (10 quadrats from each prairie) to test the relationship between fire intensity and severity. 
Next, we used the TITAN function (Taxa Indicator Threshold ANalysis) in R (Baker and King 2010) to assess how vegetation changed with increasing maximum temperature and fire severity using data from the same 50 quadrats mentioned above. The TITAN function uses a novel technique combining indicator species analysis, change point analysis (Qian et al. 2003), and randomization procedures to detect how taxa change in distribution (cover, abundance, or frequency) along a gradient, as well as to detect possible community thresholds across that gradient. A community threshold represents synchronous response of multiple taxa to the same gradient value; in this case, it would be synchronous response of life form groups to fire severity. Briefly, TITAN converts indicator values to $Z$ scores, and then sums all the $z$ scores for each point along a gradient in which a given taxa is present or absent. The highest sum $(Z)$ score of present taxa is evidence of a positive threshold, and the highest sum $(Z)$ score for absent taxa is evidence for a negative threshold (Baker and King 2010). The TITAN function also gives two values, purity and reliability, that evaluate the confidence surrounding the indicator value estimates. $\mathrm{Pu}-$ rity is the proportion of 500 bootstrap replicates with the same response direction (positive or negative). Reliability is the proportion of 500 bootstrap replicates with $P$ values $\leq$ 0.05 . Life form groups that have high purity $(>0.90)$ have high fidelity to a given response direction, and those with high reliability $(>0.90)$ have strong statistical confidence.

Influence of ignition pattern on fire intensity, fire severity, and plant community. To evaluate effects of ignition pattern on fire intensity (measured by surface temperatures), we ran a two-way ANOVA in SAS 9.3 (SAS Institute, Cary, North Carolina, USA), with ignition pattern and site as fixed effects and an alpha of 0.05. We also displayed descriptive statistics for rate of spread and flame length for both sites to help characterize the burn.
To analyze vegetation and fire severity response to ignition patterns, we used multi-response permutation procedures (MRPP) to compare treatment differences (head or backing fire) on the pre- to post-burn change in the plant community using a Bray-Curtis distance measure. The MRPP produces two test statistics, $T$ and $A$. The $T$ statistic describes the amount of separation between multivariate groups (similar to a $t$-value in a Students $t$-test); higher negative values mean stronger separation. The $A$ value is an effect size statistic, describing the degree of similarity among multivariate samples within a group. $A$ values closer to 1 signify that more samples within a group are identical, while values closer to 0 signify that more samples are different. We used non-metric multidimensional scaling (NMDS) to ordinate results using PC-ORD v6. If significant community differences were present, we used indicator species analysis (ISA) on origin-life form group to assess how the number of species within each group was associated with a given ignition pattern using the Indicator Species Function in R (Bakker 2008). We followed the same approach on the percent cover of each fire severity class per 1 $\mathrm{m}^{2}$, with the severity class as the "species."

\section{RESULTS}

\section{What Is the Relationship Between Fire Intensity, Fire Severity, and Vegetation Response to Fire?}

The fire severity index created from polar ordination represented $79 \%$ of the redundant structure in the original fire severity data matrix. Fire severity increased with increasing maximum temperature, as expected $\left(\mathrm{r}^{2}=\right.$ $0.350, P \leq 0.001)$. We did not detect any significant patterns between maximum temperature and vegetation community across the five burn units.

Six of the life form groups decreased in richness with increasing fire severity, although 
exotic perennial forbs and native and exotic grasses had the strongest and most significant responses to increasing severities (Table 1). These life form groups were associated with a synchronous negative response at FSI $=1.06$ (bootstrap percentiles: fifth percentile $=0.89$, ninety-fifth percentile $=1.23$ ). Exotic annual grasses, native annual forbs, and exotic shrubs generally increased with fire severity, but this association was weak (Table 1). The synchronous positive response of these life form groups was broad (FSI $=1.37$; bootstrap percentiles: fifth percentile $=1.02$, ninety-fifth percentile $=1.53$ )

\section{Does Fire Ignition Pattern Differentially Impact Fire Intensity and Severity?}

Observed rate of spread was more than 10 times faster in head fires compared to backing fires and average flame lengths were 2.5 to 6.8 times higher in head fires than in backing fires. The maximum surface temperatures averaged $304^{\circ} \mathrm{C}$ in areas treated with backing fire and $241^{\circ} \mathrm{C}$ in areas treated with head fire (Table
2 ), but these differences were not statistically significant at either site $\left(F_{3,19}=1.590, P=\right.$ $0.23)$, likely due to the low sample size for this metric ( $n=5$ for each ignition pattern on each prairie). At Glacial Heritage, ignition pattern affected fire severity $(T=-7.55, A=0.08, P \leq$ 0.001 ), with unburned vegetation and light severity significantly associated with head fires and moderate severity significantly associated with backing fires (Table 3). At Tenalquot, ignition pattern had no significant influence on fire severity $(T=0.21, A=-0.002, P=0.47$; Table 3). However, the percent cover of the moderate severity class was $26 \%$ greater in the backing fire (average cover per quadrat $=$ $19 \pm 11 \%$ ) than in the head fire (average cover per quadrat $=11 \pm 8 \%$ ).

\section{Does Fire Ignition Pattern Differentially Alter the Response of Native and Exotic Plant Life Forms to Prescribed Fire?}

The best NMDS solution to display the relationship between ignition pattern and vegetation was 3-dimensional (final stress $=13.11$,

Table 1. Fire severity influence on plant life form group richness in south Puget Sound prairies, Washington, USA, in 2011 and 2012. We used Taxa Indicator Threshold ANalysis (TITAN) to assess the response of plant origin $(\mathrm{N}=$ native, $\mathrm{E}=$ exotic $)$ and life form $(\mathrm{A}=$ annual, $\mathrm{P}=$ perennial, $\mathrm{G}=$ grass, $\mathrm{F}=$ forb, $\mathrm{S}=$ shrub) to fire severity. The fire severity index (FSI) columns display the median, fifth $\left(5^{\text {th }}\right)$, and ninety-fifth $\left(95^{\text {th }}\right)$ percentile FSI values taken from a frequency distribution of 500 bootstrap replicates. Thus, the range in FSI values corresponds to the magnitude of tolerance or intolerance of life form groups to increasing fire severity. Indicator values (IndVal), $P$ values, purity, and reliability are also reported. Prairies are ordered by purity for each response direction and life form group.

\begin{tabular}{ccccccccc}
\hline \multirow{2}{*}{ Response } & $\begin{array}{c}\text { Life form } \\
\text { group }\end{array}$ & FSI 5 $^{\text {th }}$ & $\begin{array}{c}\text { FSI } \\
\text { median }\end{array}$ & FSI 95 $^{\text {th }}$ & IndVal $^{*}$ Positive & $\boldsymbol{P}$ value $^{*}$ & Purity & Reliability $^{*}$ \\
& EAG & 0.88 & 1.09 & 1.49 & 35.80 & $<0.01$ & 0.86 & 0.77 \\
& NAF & 1.01 & 1.17 & 1.57 & 56.53 & 0.06 & 0.76 & 0.64 \\
& EPS & 0.88 & 1.09 & 1.53 & 39.91 & 0.16 & 0.60 & 0.36 \\
\hline \multirow{6}{*}{ Negative } & EPF & 0.89 & 1.00 & 1.38 & 59.85 & $<0.01$ & 1.00 & 0.99 \\
& EPG & 0.93 & 1.01 & 1.40 & 61.41 & $<0.01$ & 0.99 & 0.98 \\
& NPG & 1.02 & 1.15 & 1.53 & 59.70 & $<0.01$ & 0.98 & 0.97 \\
& NPS & 0.68 & 0.95 & 1.02 & 36.03 & $<0.01$ & 0.96 & 0.87 \\
& NPF & 0.88 & 1.13 & 1.49 & 58.60 & 0.05 & 0.92 & 0.78 \\
& EAF & 0.68 & 1.01 & 1.36 & 59.13 & 0.04 & 0.80 & 0.69 \\
\hline
\end{tabular}


Table 2. Fire intensity metrics by ignition pattern within two prairies in the south Puget Sound, Washington, USA, in 2011 and 2012. Where there was sufficient sample size, data are displayed as average \pm 1 SD. $\mathrm{RoS}=$ rate of spread.

\begin{tabular}{lcccccccc}
\hline & \multicolumn{3}{c}{ Glacial Heritage } & & \multicolumn{3}{c}{ Tenalquot } \\
\cline { 2 - 3 } $\begin{array}{l}\text { Ignition } \\
\text { pattern }\end{array}$ & $\begin{array}{c}\text { Flame length } \\
(\mathbf{m})\end{array}$ & $\begin{array}{c}\text { RoS } \\
\left(\mathbf{m ~ s e c}^{-1}\right)\end{array}$ & $\begin{array}{c}\text { Max. surface } \\
\text { temp. }\left({ }^{\circ} \mathbf{C}\right)\end{array}$ & $\begin{array}{c}\text { Flame length } \\
(\mathbf{m})\end{array}$ & $\begin{array}{c}\text { RoS } \\
\left(\mathbf{m ~ s e c}^{-1}\right)\end{array}$ & $\begin{array}{c}\text { Max. surface } \\
\text { temp. }\left({ }^{\circ} \mathbf{C}\right)\end{array}$ \\
\hline Backing & $0.25 \pm 0.07$ & $0.03 \pm 0.01$ & $349 \pm 12$ & & 0.20 & 0.002 & $260 \pm 109$ \\
Head & $1.70 \pm 0.57$ & $0.68 \pm 0.75$ & $254 \pm 125$ & & 0.50 & 0.15 & $227 \pm 101$ \\
\hline
\end{tabular}

Table 3. Influence of ignition pattern on plant life form richness and fire severity at two prairies in the south Puget Sound, Washington, USA, in 2011 and 2012. For each prairie, two values are reported: the indicator value (IndVal) of each plant life form group $(\mathrm{N}=$ native, $\mathrm{E}=$ exotic, $\mathrm{A}=$ annual, $\mathrm{P}=$ perennial, $\mathrm{G}$ $=$ grass, $\mathrm{F}=$ forb, $\mathrm{S}=$ shrub $)$ and fire severity class. Asterisks $(*)$ denote significant relationships $(P<$ $0.05)$ between ignition pattern and either plant life form group or fire severity.

\begin{tabular}{|c|c|c|c|c|c|}
\hline \multirow[b]{2}{*}{ Treatment } & \multirow[b]{2}{*}{ Life form grouping } & \multicolumn{2}{|c|}{ Glacial Heritage } & \multicolumn{2}{|c|}{ Tenalquot } \\
\hline & & IndVal & $P$ & IndVal & $\boldsymbol{P}$ \\
\hline \multirow{14}{*}{$\begin{array}{l}\text { Backing } \\
\text { fire }\end{array}$} & EAF & 49.79 & 0.59 & 60.42 & $0.01^{*}$ \\
\hline & EAG & 6.69 & 0.91 & 16.64 & 0.17 \\
\hline & EPF & 49.75 & 0.62 & 54.05 & $0.01 *$ \\
\hline & EPG & 43.98 & 0.87 & 49.24 & 0.68 \\
\hline & EPS & 19.23 & 0.26 & 4.67 & 0.54 \\
\hline & NAF & 46.71 & 0.52 & 49.45 & 0.17 \\
\hline & NPF & 33.68 & 1.00 & 65.36 & $0.01 *$ \\
\hline & NPG & 47.84 & 0.91 & 52.91 & 0.20 \\
\hline & Fire severity class & & & & \\
\hline & Unburned & 0.35 & 0.95 & 8.42 & 0.67 \\
\hline & Scorched & 19.41 & 0.73 & 49.68 & 0.18 \\
\hline & Light & 40.75 & 0.97 & 49.33 & 0.36 \\
\hline & Moderate & 89.77 & $<0.01 *$ & 26.99 & 0.84 \\
\hline & Heavy & 0.00 & 1.00 & 4.99 & 0.41 \\
\hline \multirow{15}{*}{$\begin{array}{c}\text { Head } \\
\text { fire }\end{array}$} & Life form grouping & & & & \\
\hline & EAF & 50.21 & 0.57 & 39.58 & 1.00 \\
\hline & EAG & 23.32 & 0.10 & 2.18 & 0.98 \\
\hline & $\mathrm{EPF}$ & 50.25 & 0.46 & 45.95 & 1.00 \\
\hline & EPG & 51.85 & 0.18 & 50.76 & 0.55 \\
\hline & EPS & 7.24 & 0.90 & 1.61 & 0.90 \\
\hline & NAF & 46.71 & 0.51 & 38.58 & 0.82 \\
\hline & NPF & 66.32 & $0.01 *$ & 33.13 & 1.00 \\
\hline & NPG & 52.16 & 0.27 & 45.04 & 0.93 \\
\hline & Fire severity class & & & & \\
\hline & Unburned & 18.08 & $0.04 *$ & 13.20 & 0.43 \\
\hline & Scorched & 32.40 & 0.24 & 29.22 & 0.81 \\
\hline & Light & 55.05 & $0.04 *$ & 46.67 & 0.64 \\
\hline & Moderate & 5.84 & 1.00 & 47.30 & 0.17 \\
\hline & Heavy & 4.76 & 0.42 & 1.46 & 0.71 \\
\hline
\end{tabular}


and instability $<0.001$ ) and the NMDS axis scores explained $89.2 \%$ of community structure $($ Axis $1=55.9 \%$, Axis $2=18 \%$, Axis $3=$ $15.4 \%$ ). Axis 1 was negatively correlated with exotic perennial forbs $\left(\mathrm{r}^{2}=0.45\right)$ and native perennial forbs $\left(\mathrm{r}^{2}=0.90\right)$. Axis 2 was positively correlated with exotic annual forbs $\left(\mathrm{r}^{2}=0.46\right)$ and exotic perennial grasses $\left(\mathrm{r}^{2}=\right.$ 0.48; Figure 1). The plant communities that experienced backing fires at Tenalquot changed more $(T=-18.14, A=0.24, P<$ $0.001)$ than those experiencing head fires $(T=$ $-16.89, A=0.21, P \leq 0.001)$, although communities in both ignition pattern treatments had similar trajectories towards more exotic perennial grasses and exotic annual forbs (Figure 1). At Glacial Heritage, communities experiencing backing fires also showed greater change $(T=-13.99, A=0.23, P \leq 0.001)$ than those experiencing head fires $(T=-13.72, A=$ $0.15, P \leq 0.001$ ), and community trajectories at this site were more variable in backing fires than in head fires, which moved towards communities with higher perennial forb richness (Figure 1).

Indicator species analysis suggested that plant life form response to ignition patterns was variable and inconsistent between the two sites. At Glacial Heritage, only native perennial forbs (NPF) were strongly associated with head fires and no plant life forms were significantly associated with backing fires, in line with patterns observed with ordinations (Table 3). At Tenalquot, native perennial forbs (NPF), exotic perennial forbs (EPF), and exotic annual forbs (EAF) were strong indicators of backing fire and no plant life forms were significantly associated with head fires. Exotic and native grasses were not associated with either ignition pattern at either site (Table 3).

\section{DISCUSSION}

Fire managers are increasingly tasked with restoring natural fire regimes to grasslands and prairies around the world, as well as navigat- ing multiple and competing management objectives for diverse taxa (Van Lear et al. 2005, Ryan et al. 2013). Thus, it is important to understand the relationship between fire intensity, severity, and vegetation effects and how fire ignition patterns influence those relationships. Across five different prescribed burns in PNW prairies, we found that maximum surface temperature was positively correlated with fire severity. This result aligns with findings from other systems (Hartford and Frandsen 1992, Chafer et al. 2004, Bradley et al. 2006) and supports the idea that the higher temperatures will consume more of the surface litter and moss, and expose more bare ground for seed germination. The TITAN analysis suggests that perennial life form groups decrease with increasing fire severity. However, the synchronous negative association of exotic perennials and exotic annual forbs with increasing fire severity could also be driven by associated herbicide management. The newly exposed soil found after severe late summer fires provides excellent germination conditions for disturbance-adapted annual species (such as Teesdalia nudicaulis [L.] W.T. Aiton) that are ubiquitous after hotter burns (Dunwiddie et al. 2014). This post-fire flush is composed primarily of exotic perennial and annual species, which are typically the first to germinate and are often more abundant compared to later germinating native species (Stanley et al. 2011). Fall herbicide management takes advantage of this phenological disparity between native and exotic species, and likely confounds direct patterns between exotic species and fire severity. We further suspect this to be true because exotic annual grasses showed the opposite trend (though weakly), and this life form group typically germinates much later after the initial fall herbicide management (A. Martin, Center for Natural Lands Management, Olympia, Washington, USA, personal observation). Thus, while higher intensity fire favors seed bank species and disturbs established shallow-rooted perennials (Pyke et al. 2010), the 


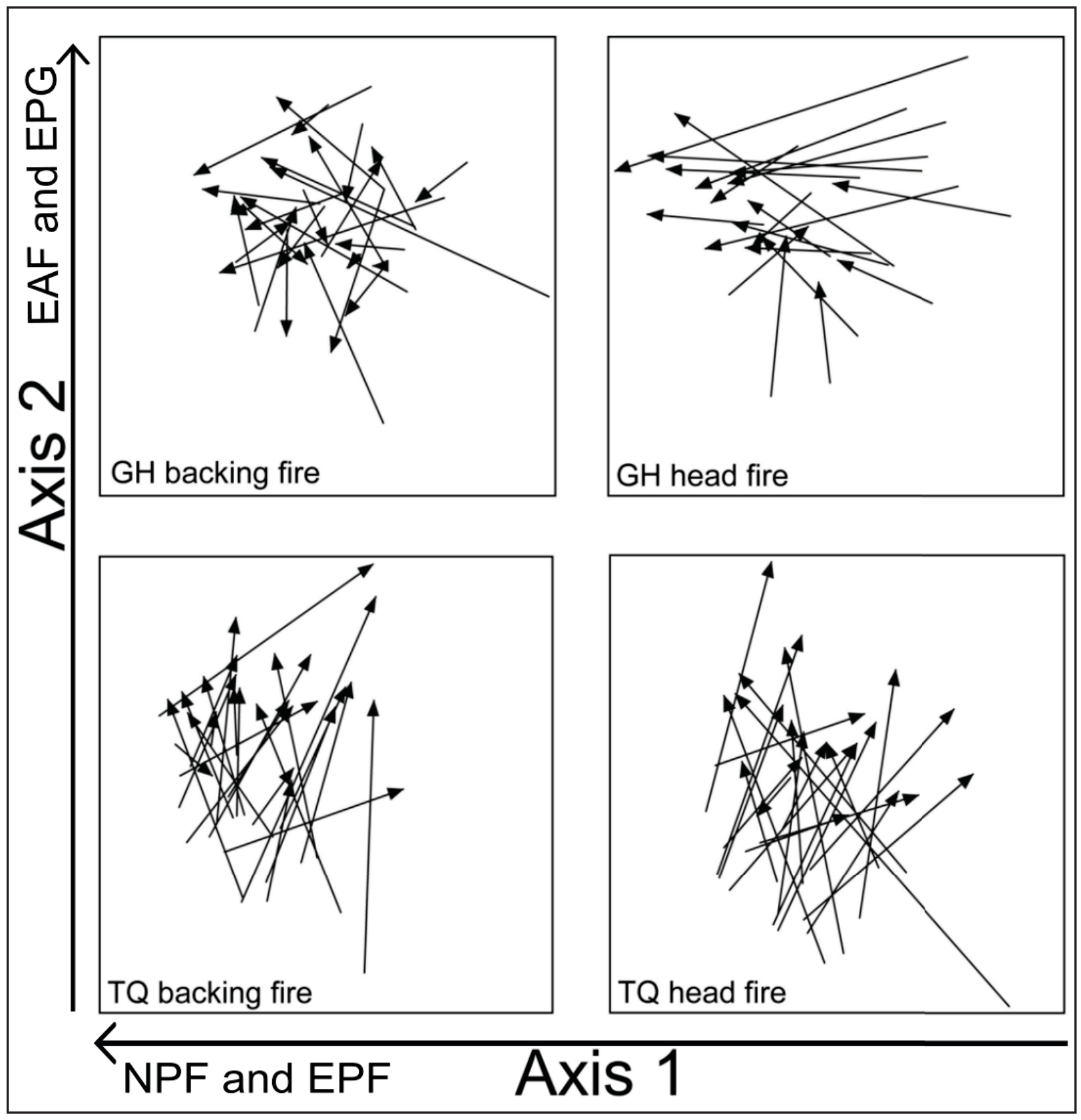

Figure 1. NMDS ordination of plant life form group by ignition pattern within two south Puget Sound prairies. Each pane shows the change in vegetation community from pre-burn to post burn for each ignition pattern at each prairie. While part of the same ordination, communities are displayed separately by site and ignition pattern to highlight patterns in each; thus, axes 1 and 2 are the same in each of the four panels. Each point represents the origin-life form group composition within a quadrat. The base of each arrow is the pre-burn community, while the point of the arrow is the post-burn community. The length of each arrow shows the magnitude of change an individual quadrat experienced from pre- to post burn. Native perennial forb (NPF) and exotic perennial forb (EPF) richness are negatively correlated with Axis 1, and exotic annual forb (EAF) and exotic perennial grass (EPG) richness is positively correlated with Axis 2. $\mathrm{GH}=$ Glacial Heritage; $\mathrm{TQ}=$ Tenalquot. 
post-burn herbicide management confounds our ability to detect those expected patterns. Future work should assess plant communities in burned areas without herbicide treatments to better assess the direct relationship between fire severity and exotic species in this system.

While several different ignition patterns are used to affect fire behavior (Johansen 1987), these strategies remain largely unexplored in the fire and restoration literature. Our study suggests that fire ignition pattern influences fire severity and post-fire vegetation in Pacific Northwest prairies. Although average maximum surface temperature did not vary between the two ignition pattern treatments, a 10-fold difference in residence time suggests that the duration of heating may be an important factor influencing vegetation response to ignition patterns. This reflects a fundamental difference between the behavior of head and backing fires: head fires spread rapidly among the tops of the grasses, spending less time on the surface, quickly influencing large acreages; backing fires have longer residence times, allowing more thorough combustion of plant material, typically over smaller areas (Keeley 2009). This pattern aligns well with our finding at Glacial Heritage that backing fires were more severe compared to head fires.

Ignition patterns caused community level shifts in plant life forms, although shifts were not consistent between burns. These variable responses were likely driven by different site histories. The burn unit at Glacial Heritage consisted of remnant native prairie with high native plant richness, low moss depth, and a history of multiple burns in the past decade. This created an initial heterogeneous plant community with low aboveground fuels, which possibly explains the different community trajectories between ignition patterns. The ecological objective for the burn was to remove standing dead litter and maintain current vegetative composition. At Tenalquot, the burn was the first in that section of prairie in recorded history, and the site itself is a degrad- ed horse pasture with low remnant native plant richness, high pasture grass cover, and high moss depth and cover. The ecological objective at Tenalquot was to remove dead litter and moss and prepare the site for native enhancement. The lower overall severity of the fire and the lack of strong differences in severity between ignition patterns likely caused the whole plant community to shift in similar ways. Thus, these initial starting conditions could have facilitated the resulting responses to the two ignition pattern treatments.

Residence time and fire severity are key factors determining whether individual plants experiencing fire will survive or perish (Pyke et al. 2010). Many of the remnant native plant species in PNW prairies are geophytes, remaining dormant belowground during the burning season, while many of the exotic species are active year-round or remain dormant with rhizomes (primarily grasses) at or above the soil surface (Dennehy et al. 2011). Since head fires are less likely to heat more than the top $1 \mathrm{~cm}$ of soil, it is possible that individual plants can persist through these types of burns, while backing fires may have more detrimental impacts on exotic species than on native species by heating surface soils (and their associated biological structures) to lethal temperatures (Neary et al. 1999). Also, due to a century of fire exclusion, many of the prairies in the PNW have a thick moss layer (Hamman et al. 2011), and if the fire does not penetrate and consume some of the moss, plants dormant below the soil surface are more likely to be protected from lethal heat. Since our prairies are native-seed limited (Stanley et al. 2008), the removal of exotic perennial grasses from both sites may have allowed exotic annual forb and exotic perennial forb species in the seedbank (10 out of the 13 new exotic species detected post burn were forbs) to dominate post fire.

Our inability to detect a positive increase in native annual forbs is likely due to this group's near eradication from the prairie landscape (Dunwiddie et al. 2006, Dunwiddie et 
al. 2014). If more species were present in this group, it is likely that post-fire patterns would mirror exotic annual forbs (Dunwiddie et al. 2014). This is also likely the case for native perennial grass, which has a low overall richness in the ecoregion $(<15$ species; Dunwiddie et al. 2006). Since only one native perennial grass was actively seeded ( $F$. roemeri), and overall richness of native perennial grasses was low, the ability to detect an overall trend in richness was diminished.

Finally, there are a few caveats to our findings. Our study was observational, and was an attempt to answer Dunwiddie's (1995) plea to share observations and insights gleaned from land management activities, even when they are not set up as a rigorous experimental studies. With that said, care should be taken in generalizing from our results. Year, site, season, and even day of burn influence fire effects (Ryan et al. 2013), and many historical and biogeographical factors influence the taxa present at a site, as well as their frequency and abundance. We suspect that it will take many burns across many sites and years before consistent general patterns linking vegetation and fire severity emerge. However, our results suggest that detailed knowledge of site history and the natural history of the plant taxa present, something most site managers possess, can inform hypotheses surrounding fire management outcomes.
Even in light of our caveats, when our data were partitioned by ignition pattern, novel interactions became evident and the heterogeneity of fire and vegetation response could be partially explained by ignition patterns. Since there is a paucity of published studies investigating how ignition patterns interact with fire severity to shape post-fire plant communities (Bidwell et al. 1990), we hope that this paper will promote further inquiry into how fire ignition patterns can influence postfire community response. Species richness within key plant life forms provided one important, though coarse, look at how different types of fire influence the trajectory of community recovery. Future work should assess how ignition pattern and severity interact with plant life form cover, individual species responses, and specific life history stages. The ability of individual species to survive or germinate post fire is fundamental to community organization post disturbance, and assessing the influence of ignition patterns will likely become increasingly useful to future restoration efforts and invasive species management. If similar findings are repeatable and consistent across multiple burns and prairies, this will not only provide a relatively novel way of interpreting vegetation response, but also allow for land managers to more precisely make fire prescriptions to achieve desired restoration outcomes.

\section{ACKNOWLEDGEMENTS}

We'd like to thank the 2011 and 2012 Center for Natural Lands Management science interns and AmeriCorps members for assisting with data collection, and M. McKinley and P. Dunwiddie for helping orchestrate the burn treatments. This manuscript was substantially improved by comments from J. Bakker and P. Dunwiddie and two anonymous reviewers. This project was funded through Department of Defense's Army Compatible Use Buffer Program at Joint Base Lewis-McChord.

\section{LITERATURE CITED}

Agee, J.K. 1996. Achieving conservation biology objectives with fire in the Pacific Northwest. Weed Technology 10: 417-421. 
Baker, M.E., and R.S. King. 2010. A new method for detecting and interpreting biodiversity and ecological community thresholds. Methods in Ecology and Evolution 1(1): 25-37. doi: 10.1111/j.2041-210X.2009.00007.x

Bakker, J.D. 2008. Increasing the utility of Indicator Species Analysis. Journal of Applied Ecology 45: 1829-1835. doi: 10.1111/j.1365-2664.2008.01571.x

Bidwell, T.G., D.M. Engle, and P.L. Claypool. 1990. Effects of spring headfires and backfires on tallgrass prairie. Journal of Range Management 43: 211-214. doi: 10.2307/3898674

Boyd, R. 1999. Indians, fire and the land in the Pacific Northwest. Oregon State University Press, Corvallis, USA.

Bradley, T., J. Gibson, and W. Bunn. 2006. Fire severity and intensity during spring burning in natural and masticated mixed shrub woodlands. Pages 419-428 in: P.L. Andrews and B.W. Butler, compilers. Proceedings of the conference: Fuels Management-How to Measure Success. USDA Forest Service Proceedings RMRS-P-41, Rocky Mountain Research Station, Fort Collins, Colorado, USA.

Brown, R.T., J.K. Agee, and J.F. Franklin. 2004. Forest restoration and fire: principles in the context of place. Conservation Biology 18: 903-912. doi: 10.1111/j.1523-1739.2004.521_1.x

Chafer, C.J., M. Noonan, and E. Macnaught. 2004. The post-fire measurement of fire severity and intensity in the Christmas 2001 Sydney wildfires. International Journal of Wildland Fire 13: 227-240. doi: 10.1071/WF03041

Covington, W.W. 2003. Restoring ecosystem health in frequent-fire forests of the American West. Ecological Restoration 21: 7-11. doi: 10.3368/er.21.1.7

Dennehy, C., E.R. Alverson, H.E. Anderson, D.R. Clements, and T.N. Kaye. 2011. Management strategies for invasive plants in Pacific Northwest prairies, savannas, and oak woodlands. Northwest Science 85: 329-351. doi: 10.3955/046.085.0219

DiTomaso, J.M., M.L. Broooks, E.B. Allen, R. Minnich, P.M. Rice, and G.B. Kyser. 2006. Control of invasive weeds with prescribed burning. Weed Technology 20: 535-548. doi: 10.1614/WT-05-086R1.1

Dunwiddie, P.W. 1995. (Research + observations) - publication $\neq$ science? Natural Areas Journal 15: 3 .

Dunwiddie, P., E. Alverson, A. Stanley, R. Gilbert, S. Pearson, D. Hays, J. Arnett, E. Delvin, D. Grosboll, and C. Marschner. 2006. The vascular plant flora of the South Puget Sound prairies, Washington, USA. Davidsonia 14: 51-69.

Dunwiddie, P.W., E.R. Alverson, R.A. Martin, and R. Gilbert. 2014. Annual species in native prairies of south Puget Sound, Washington. Northwest Science 88: 94-105. doi: 10.3955/046.088.0205

Foster, J.R., and S.E. Shaff. 2003. Forest colonization of Puget lowland grasslands at Fort Lewis, Washington. Northwest Science 77: 283-296.

Hamman, S.T., P.W. Dunwiddie, J.L. Nuckols, and M. McKinley. 2011. Fire as a restoration tool in Pacific Northwest prairies and oak woodlands: challenges, successes, and future directions. Northwest Science 85: 317-328. doi: 10.3955/046.085.0218

Hartford, R.A., and H. Frandsen. 1992. When it's hot, it's hot... or maybe it's not! (surface flaming may not portend extensive soil heating). International Journal of Wildland Fire 2: 139144. doi: 10.1071/WF9920139

Haubensak, K.A., C.M. D’Antonio, and J. Alexander. 2004. Effects of nitrogen-fixing shrubs in Washington and coastal California. Weed Technology 18: 1475-1479. doi: 10.1614/0890-037X(2004)018[1475:EONSIW]2.0.CO;2 
Hurlbert, S.H. 1984. Pseudoreplication and the design of ecological field experiments. Ecological Monographs 54: 187-211. doi: 10.2307/1942661

Johansen, R.W. 1987. Ignition patterns and prescribed fire behavior in southern pine stands. Georgia Forestry Commission Research Paper 72, Macon, Georgia, USA.

Keeley, J.E. 2009. Fire intensity, fire severity and burn severity: a brief review and suggested usage. International Journal of Wildland Fire 18: 116-126. doi: 10.1071/WF07049

Kilgore, B.M., and G.A. Curtis. 1987. Guide to understory burning in ponderosa pine-larch-fir forests in the Intermountain West. USDA Forest Service General Technical Report INT-233, Intermountain Research Station, Ogden, Utah, USA.

Neary, D.G., C.C. Klopatek, L.F. DeBano, and P.F. Ffolliott. 1999. Fire effects on belowground sustainability: a review and synthesis. Forest Ecology and Management 122: 51-71. doi: 10.1016/S0378-1127(99)00032-8

Oksanen, L. 2003. Logic of experiments in ecology: is pseudoreplication a pseudoissue? Oikos 94(1): 27-38. doi: 10.1034/j.1600-0706.2001.11311.x

Perry, D.A., P.F. Hessburg, C.N. Skinner, T.A. Spies, S.L. Stephens, A.H. Taylor, J.F. Franklin, B. McComb, and G. Riegel. 2011. The ecology of mixed severity fire regimes in Washington, Oregon and northern California. Forest Ecology and Management 262: 703-717. doi: 10.1016/j.foreco.2011.05.004

Pyke, D.A., M.L. Brooks, and C. D’Antonio. 2010. Fire as a restoration tool: a decision framework for predicting the control or enhancement of plants using fire. Restoration Ecology 18: 274-284. doi: 10.1111/j.1526-100X.2010.00658.x

Qian, S.S., R.S. King, and C.J. Richardson. 2003. Two methods for the detection of environmental thresholds. Ecological Modelling 166: 87-97. doi: 10.1016/S0304-3800(03)00097-8

R Core Team. 2014. R: a language and environment for statistical computing. R Foundation for Statistical Computing, Vienna, Austria.

Ryan, K.C, E.E. Knapp, and J.M. Varner. 2013. Prescribed fire in North American forests and woodlands: history, current practice, and challenges. Frontiers in Ecology and the Environment 11: e15-e24. doi: 10.1890/120329

Schoennagel, T., T.T. Veblen, and W.H. Romme. 2004. The interaction of fire, fuels and climate across Rocky Mountain forests. Bioscience 54: 661-676. doi: 10.1641/0006-3568 (2004)054[0661:TIOFFA]2.0.CO;2

Seabloom, E.W., W.S. Harpole, O.J. Reichman, and D. Tilman. 2003. Invasion, competitive dominance, and resource use by exotic and native California grassland species. Proceedings of the National Academy of Sciences of the United States of America 100: 13384-13389. doi: 10.1073/pnas.1835728100

Stanley, A.G., T.N. Kaye, and P.W. Dunwiddie. 2008. Regional strategies for restoring invaded prairies: observations from a multisite, collaborative research project. Native Plants Journal 9: 247-254. doi: 10.2979/NPJ.2008.9.3.247

Stanley, A.G., P.W. Dunwiddie, and T.N. Kaye. 2011. Restoring invaded Pacific Northwest prairies: management recommendations from a region-wide experiment. Northwest Science 85: 233-246. doi: 10.3955/046.085.0212

Storm, L., and D. Shebitz. 2006. Evaluating the purpose, extent, and ecological restoration applications of indigenous burning practices in southwestern Washington. Ecological Restoration 24: 256-268. doi: 10.3368/er.24.4.256

Turner, M.G., W.H. Romme, and R.H. Gardner. 1999. Pre-fire heterogeneity, fire severity, and early post-fire plant reestablishment in subalpine forests of Yellowstone National Park, Wyoming. International Journal of Wildland Fire 9: 21-36. doi: 10.1071/WF99003 
USDI National Park Service. 2003. Fire monitoring handbook. Fire Management Program Center, National Interagency Fire Center, Boise Idaho, USA.

Van Lear, D.H., W.D. Carroll, P.R. Kapeluck, and R. Johnson. 2005. History and restoration of the longleaf pine-grassland ecosystem: implications for species at risk. Forest Ecology and Management 211: 150-165. doi: 10.1016/j.foreco.2005.02.014

Van Wilgen, B.W., N. Govender, J.C. Biggs, D. Ntsala, and X.N. Funda. 2004. Response of savanna fire regimes to changing fire management policies in a large African national park. Conservation Biology 18: 1533-1540. doi: 10.1111/j.1523-1739.2004.00362.x

Wagner, V., and C.R. Nelson. 2014. Herbicides can negatively affect seed performance in native plants. Restoration Ecology 22: 288-291. doi: 10.1111/rec.12089

Wray, J., and M.K. Anderson. 2003. Restoring Indian-set fires to prairie ecosystems on the Olympic Peninsula. Ecological Restoration 21: 296-301. doi: 10.3368/er.21.4.296 